\title{
Noble metal-modified titania with visible-light activity for the decomposition of microorganisms
}

\author{
Maya Endo ${ }^{1}$, Zhishun Wei ${ }^{1,2}$, Kunlei Wang ${ }^{1,3}$, Baris Karabiyik ${ }^{1}$, Kenta Yoshiiri ${ }^{1,3}$, \\ Paulina Rokicka ${ }^{1,4}$, Bunsho Ohtani ${ }^{1,3}$, Agata Markowska-Szczupak ${ }^{* 1,4}$ \\ and Ewa Kowalska*1,3
}

\section{Full Research Paper}

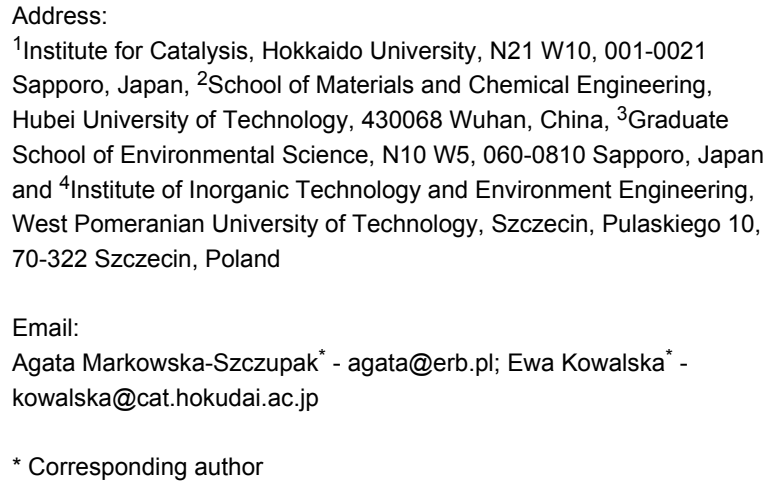

${ }^{1}$ Institute for Catalysis, Hokkaido University, N21 W10, 001-0021 Sapporo, Japan, ${ }^{2}$ School of Materials and Chemical Engineering, Hubei University of Technology, 430068 Wuhan, China, ${ }^{3}$ Graduate School of Environmental Science, N10 W5, 060-0810 Sapporo, Japan and ${ }^{4}$ Institute of Inorganic Technology and Environment Engineering, West Pomeranian University of Technology, Szczecin, Pulaskiego 10 70-322 Szczecin, Poland

Beilstein J. Nanotechnol. 2018, 9, 829-841. doi:10.3762/bjnano.9.77

Received: 01 October 2017

Accepted: 02 February 2018

Published: 07 March 2018

This article is part of the Thematic Series "Energy conversion, storage and environmental remediation using nanomaterials".

Guest Editor: W.-J. Ong

(C) 2018 Endo et al.; licensee Beilstein-Institut. License and terms: see end of document.

\begin{abstract}
Commercial titania photocatalysts were modified with silver and gold by photodeposition, and characterized by diffuse reflectance spectroscopy (DRS), X-ray powder diffraction (XRD), X-ray photoelectron spectroscopy (XPS) and scanning transmission electron microscopy (STEM). It was found that silver co-existed in zero valent (core) and oxidized (shell) forms, whereas gold was mainly zero valent. The obtained noble metal-modified samples were examined with regard to antibacterial (Escherichia coli (E. coli)) and antifungal (Aspergillus niger (A. niger), Aspergillus melleus (A. melleus), Penicillium chrysogenum (P. chrysogenum), Candida albicans (C. albicans)) activity under visible-light irradiation and in the dark using disk diffusion, suspension, colony growth ("poisoned food") and sporulation methods. It was found that silver-modified titania, besides remarkably high antibacterial activity (inhibition of bacterial proliferation), could also decompose bacterial cells under visible-light irradiation, possibly due to an enhanced generation of reactive oxygen species and the intrinsic properties of silver. Gold-modified samples were almost inactive against bacteria in the dark, whereas significant bactericidal effect under visible-light irradiation suggested that the mechanism of bacteria inactivation was initiated by plasmonic excitation of titania by localized surface plasmon resonance of gold. The antifungal activity tests showed efficient suppression of mycelium growth by bare titania, and suppression of mycotoxin generation and sporulation by gold-modified titania. Although, the growth of fungi was hardly inhibited through disc diffusion (inhibition zones around discs), it indicates that gold does not penetrate into the media, and thus, a good stability of plas-
\end{abstract}


monic photocatalysts has been confirmed. In summary, it was found that silver-modified titania showed superior antibacterial activity, whereas gold-modified samples were very active against fungi, suggesting that bimetallic photocatalysts containing both gold and silver should exhibit excellent antimicrobial properties.

\section{Introduction}

Environmental pollution and the lack of clean potable water are main issues facing human development. Although, various methods of efficient control and monitoring of waste management have been successfully applied in developed countries, pollution in low-income countries is still a major environmental and public health challenge. It is thought that in developing countries, the quest for poverty reduction and economic development results in little consideration for environmental issues. Although, weak environmental regulatory institutions often undermine conventional command-and-control policies in these countries [1], various techniques and methods of water purification, such as disinfection, have already been applied. During disinfection, vegetative forms of microorganisms are destroyed or deactivated through interfering with cell activity (e.g., changes in cell permeability, enzyme activity and cell division). It is believed that in the history of humanity, disinfection is one of the most important achievements in the health protection [2]. Improvements in sanitation facilities and watertreatment methods have reduced the spread of many infectious diseases (e.g., cholera and dysentery), whereas the sterilization practices in hospitals have prevented the transition of infectious pathogens to patients. Water disinfection is usually carried out by chlorination, and sometimes by more expensive methods, such as UV irradiation and ozonation. Although, chlorine can inactivate some microorganisms completely, it may also negatively influence water environment, and even animal and human health, e.g., the chlorination by-products are mutagenic and carcinogenic [3]. Moreover, chlorine disinfection has only a low effect on some pathogenic protozoa (e.g., Cryptosporidium sp. responsible for diarrhoea and even the death of immunocompromised patients) and viruses (e.g., norovirus). In contrast, UV disinfection is highly efficient against various microorganisms (even viruses) since absorption of UV light $(\lambda=253.7 \mathrm{~nm})$ by nucleic acids induces the damage of genetic information and inactivation. However, it should be pointed out that chlorine disinfection is often complementary used because: (i) some viruses have low sensitivity to UV irradiation (e.g., adenovirus), and (ii) the lack of residual disinfection of UV irradiation (only during treatment/direct irradiation). Ozone disinfection is also efficient for the degradation of microorganisms, either directly by ozone molecules or by formed oxidative radicals. However, it should be reminded that ozone itself is harmful and can initiate the formation of toxic compounds. Moreover, ozonation and UV irradiation are quite expensive technologies considering both investment and exploration costs.
Accordingly, inorganic antimicrobial agents have been extensively investigated for water purification since they are stable and environmentally safe. Historically, noble metals such as gold, silver and copper have been used since ancient times for the treatment of many diseases and illnesses or for the disinfection of water. In ancient Greece and Rome, the silver or gold dishes left in the sun were believed to protect people against pathogenic microorganisms, and silver coins thrown into the water prolonged its freshness [4-6]. Recent advances in nanotechnology enable to utilize size-dependent properties of nanomaterials, such as high specific surface area, high reactivity, quantum-size effects and plasmonic properties. Nanosilver and nanogold have already been used for various antimicrobial applications, such as (i) ionization techniques, (ii) membrane technologies to reduce biofouling of sanitation devices, (iii) development of sensors with high sensitivity and selectivity for pathogen detection, (iv) everyday products (cosmetics, shoes, clothes and dental treatment). For example, slowly released nanosilver has been used in a variety of domestic appliances, such as washing machines (e.g., Samsung SilverNanoHealth technology). Moreover, antibacterial properties of noble metals have been applied for medical purposes, including healing of burn wounds (bandage and dressing), and protection against infection (braces and catheters).

Photocatalysis is considered as one of the best methods for environmental purification since additional chemical compounds, such as strong oxidants (ozone, hydrogen peroxide or chlorine) [7-14], are not introduced into the environment $[15,16]$. The energy consumption is also much lower than that of other advanced oxidation technologies (AOTs), e.g., wet air oxidation [17], supercritical water oxidation [18], or $\mathrm{H}_{2} \mathrm{O}_{2} / \mathrm{UV}-$ $\mathrm{C}$ [19]. That is because UV-A lamps or even solar radiation can be used for photocatalyst activation [20]. Titanium(IV) oxide (titania) is the most widely used semiconductor photocatalyst used in treatment of water/wastewater and air [21]. The major barrier for common application of titania photocatalysis is the low activity under solar radiation (mainly due to wide band gap of titania of 3.0-3.2 eV and the recombination of charge carriers). There are various ways to improve photocatalytic performance of titania photocatalysts: (1) to inhibit the recombination of charge carriers, and (2) to extend its working abilities to the visible-light region, for example, by morphology design [22-26], surface modification [27-32], doping [33-36], or the formation of heterojunctions with other semiconductors [37- 
40]. Modification with noble metals seems the most promising as it is well known that under UV irradiation, noble metals work as an electron pool retarding the recombination of charge carriers [41-43], whereas under visible-light irradiation titania is activated by the plasmonic properties of noble metals ("plasmonic photocatalysis") $[44,45]$. Accordingly, it has been proposed that the combination of the antimicrobial properties of noble metals with the high photocatalytic activity of modified titania should result in a high purification efficiency of noble metal-modified titania [6,46-52]. Indeed, in our recent study, noble metal-modified faceted anatase titania (octahedral anatase particles; OAP) have shown high activity in both the decomposition of organic compounds and of microorganisms (E. coli and C. albicans) [48]. It has been found that both the intrinsic properties of silver and the photocatalytic activity of silver-modified titania are responsible for the high antibacterial activity under visible-light irradiation, whereas the size and shape of silver nanoparticles (NPs) and the aspect ratio of titania affect the antifungal activity [29]. In the present study, antimicrobial properties of commercial titania samples modified with noble metals have been investigated in order to further clarify (1) the mechanism of antimicrobial action of plasmonic photocatalysts, (2) key factors of the high activity against various microorganisms, (3) the correlation between the inactivation and complete decomposition of bacteria, (4) the inhibition of filamentous fungal growth and sporulation by using a new evaluation method.

\section{Results and Discussion Characterization of titania samples modified with NPs of silver and gold}

Six commercial titania samples were modified with gold or silver by photodeposition [53,54]. In brief, during photodeposition, metal cations were reduced by photogenerated electrons on irradiated titania. To enable a efficient deposition of metals on titania, photodeposition was carried out in $50 \mathrm{vol} \%$ methanol as a hole scavenger and under anaerobic conditions to avoid electron scavenging by oxygen. To find the key factors of antimi- crobial activity, various titania samples modified with noble metal NPs (NMNPs) were investigated. The NMNPs differ in crystallographic composition, crystallite sizes and specific surface area. It was confirmed that properties of titania influenced the resultant properties of NMNPs [53], as shown in Table 1. Min et al. proposed that gold clusters were preferentially deposited on surface defects of the support [55]. Therefore, fine titania with a high number of defects (electron traps, ETs) induced the formation of fine and well-dispersed NMNPs on titania surface, as shown in Figure 1 (top). In contrast, titania with large crystals (low number of ETs) induced the aggregation of NMNPs on its well-crystallized surface (Figure 1 (bottom)). It was found that silver formed smaller NPs than gold, as shown in Figure 1 (left and right, respectively).

To investigate the surface properties of the deposited noble metals, XPS analysis was performed, and exemplary data are shown in Figure 2. XPS peaks of $\mathrm{Au} 4 \mathrm{f}_{7 / 2}$ and $\mathrm{Ag} 3 \mathrm{~d}_{5 / 2}$ were assigned to two and/or three components, i.e., $\mathrm{Au}^{\delta+}, \mathrm{Au}^{0}$ and $\mathrm{Au}^{\delta-}$ for binding energies (BE) of ca. 83.0, 82.5 and $82.0 \mathrm{eV}$, respectively, and $\mathrm{Ag}^{0}, \mathrm{Ag}^{+}$and $\mathrm{Ag}^{2+}$ for $\mathrm{BE}$ of ca. 368.4, 367.4 and $366.3 \mathrm{eV}$, respectively. It was found that gold existed mainly in zero valent form, whereas silver existed in both zero valent and oxidized forms (mainly as $\mathrm{Ag}^{+}$). It is proposed that although zero valent silver NPs were formed during photodeposition (brown colour of suspension, which is characteristic for spherical silver NPs with localized surface plasmon resonance (LSPR) at ca. 410-430 nm), they were easily oxidized under ambient conditions, and the resultant silver deposits on titania were composed of a zero valent silver core and a silver oxide shell. XRD analysis confirmed XPS data showing silver in three oxidation states $(\operatorname{Ag}(0), \operatorname{Ag}(\mathrm{I})$ and $\operatorname{Ag}(\mathrm{II}))$, as shown in Figure 3.

All modified titania samples were coloured due to LSPR of NMNPs. Gold-modified samples were violet (light violet for larger titania and gold NPs $\left(\mathrm{Au} / \mathrm{TiO}_{2}(\mathrm{ST} 41), \mathrm{Au} / \mathrm{TiO}_{2}(\mathrm{FP} 6)\right)$ and dark violet for smaller particle sizes $\left(\mathrm{Au} / \mathrm{TiO}_{2}\right.$ (TIO12),

\begin{tabular}{|c|c|c|c|c|c|c|}
\hline \multirow[t]{2}{*}{ titania } & \multirow[t]{2}{*}{ phase $^{a}$} & \multirow[t]{2}{*}{$\operatorname{size}^{\mathrm{b}} / \mathrm{nm}$} & \multirow[t]{2}{*}{$\mathrm{ET} / \mathrm{mmol} \cdot \mathrm{g}^{-1}$} & \multirow[t]{2}{*}{$\mathrm{BET} / \mathrm{m}^{\mathrm{d}} \cdot \mathrm{g}^{-1}$} & \multicolumn{2}{|c|}{$\mathrm{NP}$ size $\mathrm{e} / \mathrm{nm}$} \\
\hline & & & & & $\mathrm{Au}$ & $\mathrm{Ag}$ \\
\hline ST01 & anatase & $8^{f}$ & $84^{f}$ & $298^{f}$ & 8 & 0.99 \\
\hline ST41 & anatase & $205^{f}$ & $25^{f}$ & $11^{f}$ & 29 & 20 \\
\hline TIO12 & anatase & $6^{f}$ & $111^{f}$ & $290^{f}$ & 14 & - \\
\hline FP6 & anatase/r & 12 & - & 97 & - & 6 \\
\hline TIO6 & rutile & $15^{f}$ & $242^{f}$ & $100^{f}$ & 14 & - \\
\hline STF10 & rutile/a & 102 & $71^{f}$ & $12^{f}$ & 23 & 22 \\
\hline
\end{tabular}

${ }^{a}$ crystal phase ( $r$ : small content of rutile and a: small content of anatase), ${ }^{b}$ crystallite size of the dominant titania phase, ${ }^{c}$ content of electron traps, $\mathrm{d}_{\text {specific surface area, }}{ }^{\mathrm{e}}$ crystallite size of metal NPs, ${ }^{\mathrm{f}} \mathrm{g}_{\text {data }}$ reported previously in $[56,57]$, respectively. 

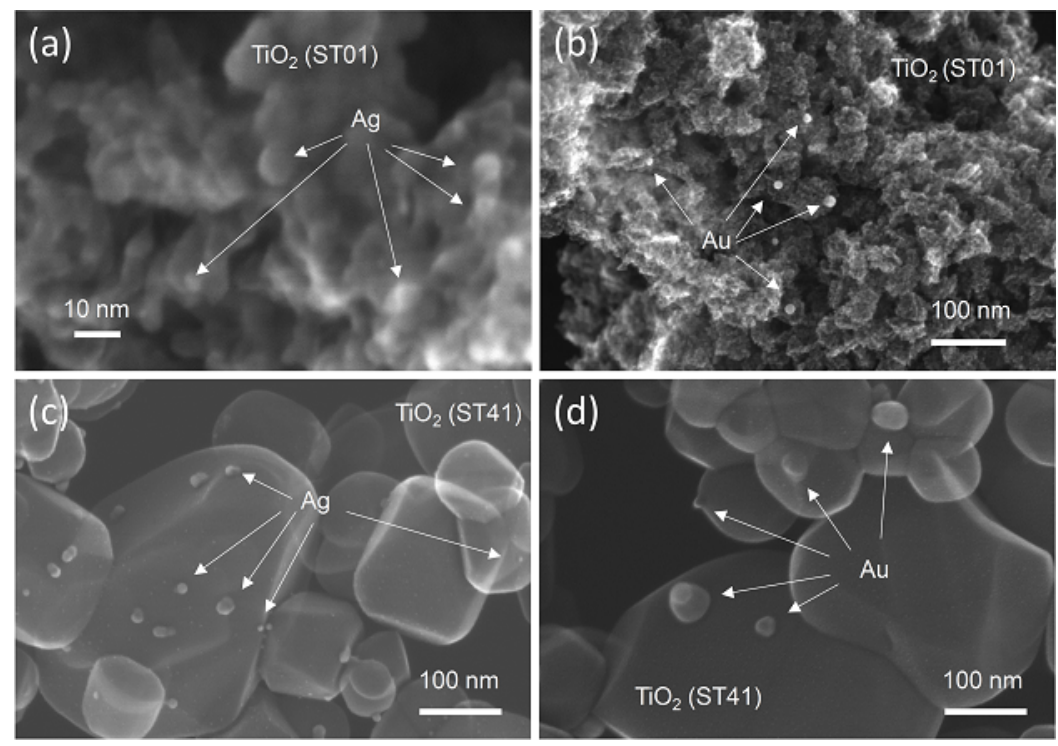

Figure 1: STEM images of modified titania samples: (a) $\mathrm{Ag} / \mathrm{TiO}_{2}\left(\mathrm{ST} 1\right.$ 1), (b) $\mathrm{Au} / \mathrm{TiO}_{2}(\mathrm{ST01})$, (c) $\mathrm{Ag} / \mathrm{TiO}_{2}(\mathrm{ST} 41)$ and (d) $\mathrm{Au} / \mathrm{TiO}{ }_{2}(\mathrm{ST} 41$ ).
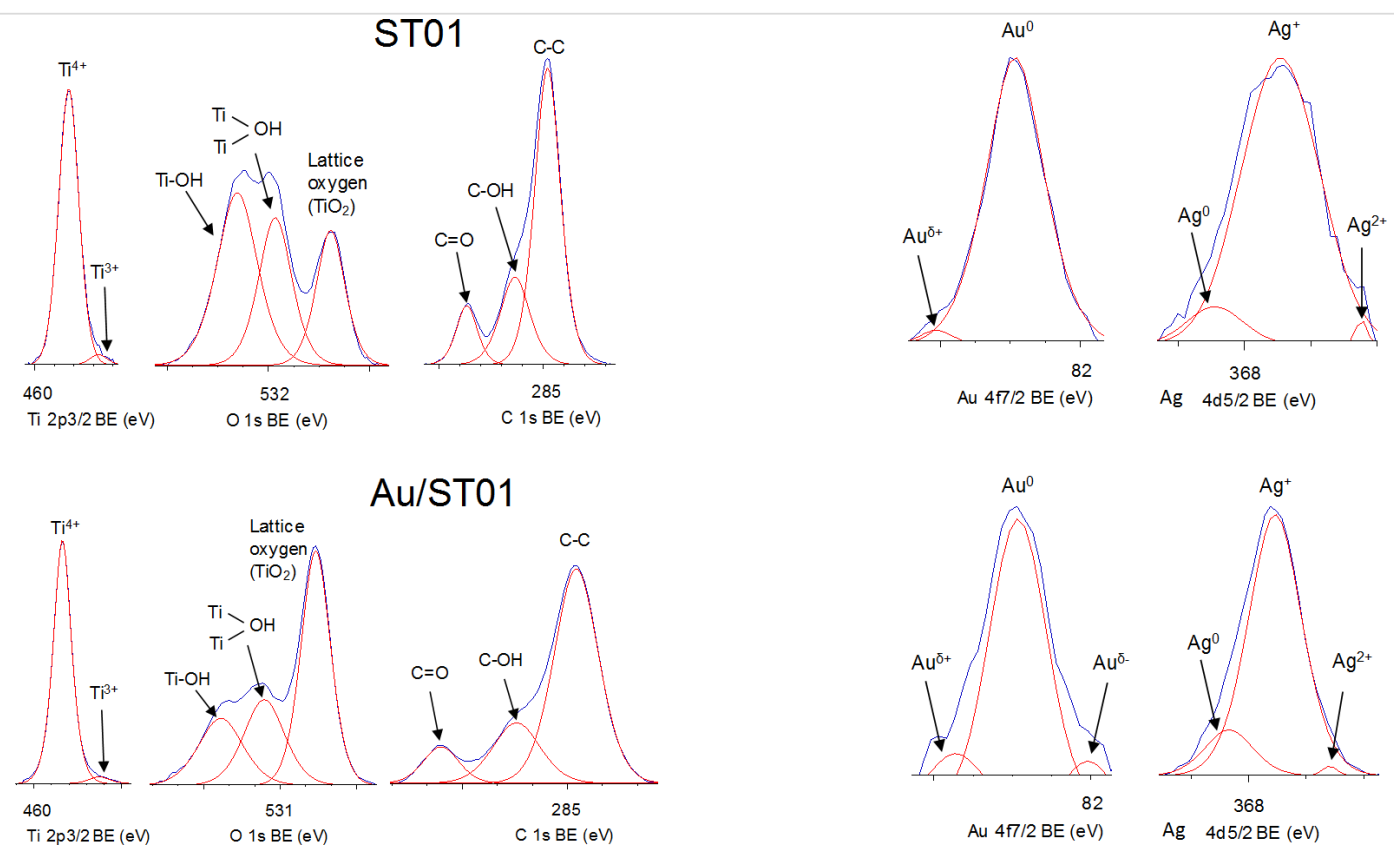

\section{$\mathrm{Au} / \mathrm{ST01}$}
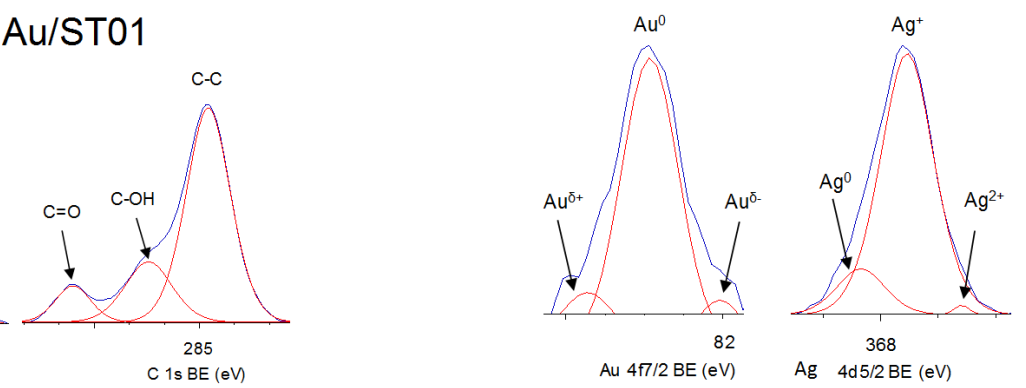

Figure 2: XPS spectra for bare (top left) and gold-modified (bottom left) $\mathrm{TiO}_{2}$ (ST01) sample, and deconvoluted peaks of $\mathrm{Au} 4 \mathrm{f}_{7 / 2}$ (center) and Ag $3 \mathrm{~d}_{5 / 2}$ (right) for metal-modified ST01 (top) and ST41 (bottom).

$\left.\mathrm{Au} / \mathrm{TiO}_{2}(\mathrm{ST} 01)\right)$, and silver-modified samples were brownviolet. Exemplary diffuse reflectance spectra (DRS) are shown in Figure 4. It should be pointed out that LSPR of silver could overlap with photoabsorption of titania, and thus to obtain clear LSPR peak of silver, DRS taken with bare titania as reference is recommended (Figure 4 (right)). The intrinsic absorption of anatase titania was observed at wavelengths shorter than $400 \mathrm{~nm}$ $\left(E_{\mathrm{g}}>3 \mathrm{eV}\right)$, and LSPR peaks appeared at longer wavelengths for gold NPs $\left(\lambda_{\max }\right.$ at ca. $\left.560 \mathrm{~nm}\right)$ than for silver NPs $\left(\lambda_{\max }\right.$ at ca. $450 \mathrm{~nm}$ ), correlating well with reported data for spherical NPs of gold and silver [58].

\section{Antibacterial activities of plasmonic photocatalysts}

At first, the antibacterial properties of bare titania samples were investigated, and data are presented in Supporting Information File 1 (Table S1). In the dark, antibacterial properties of bare titania samples were very low reaching $15.4 \%, 16.4 \%$ and 

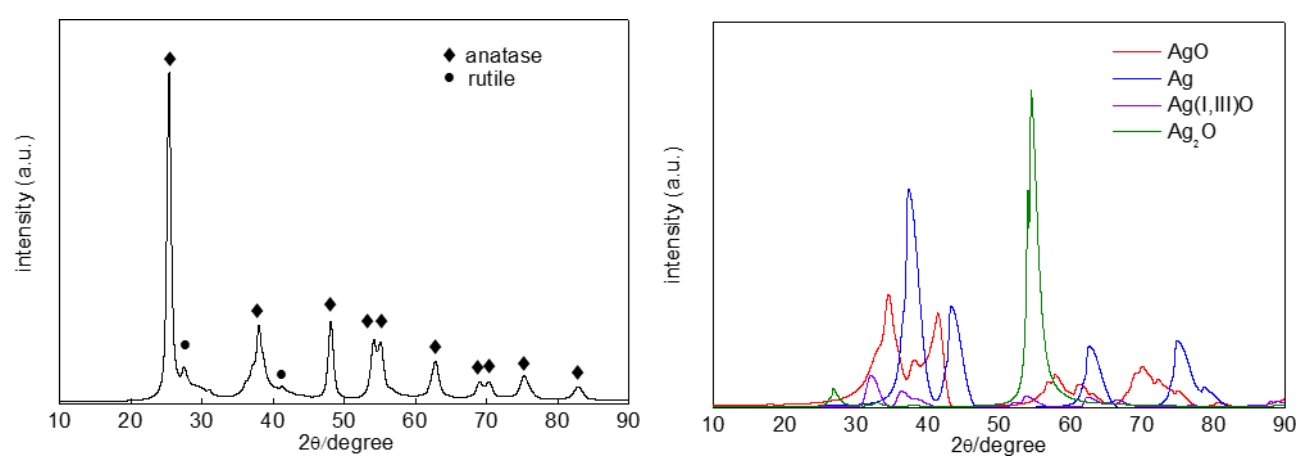

Figure 3: XRD patterns of $\mathrm{Ag} / \mathrm{TiO}_{2}(\mathrm{FP} 6)$ : (left) original pattern, and (right) after subtraction of titania peaks.
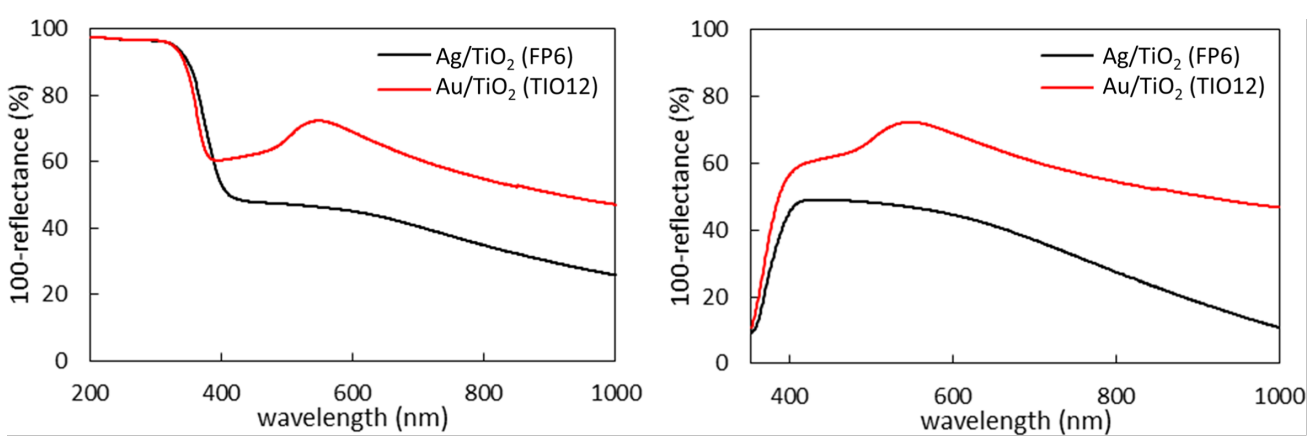

Figure 4: $\mathrm{DRS}$ spectra of $\mathrm{Ag} / \mathrm{TiO}_{2}(\mathrm{FP} 6)$ and $\mathrm{Au} / \mathrm{TiO}_{2}(\mathrm{TIO} 12)$ taken with $\mathrm{BaSO}_{4}$ (left) and respective bare titania (right) as a reference.

$23.7 \%$ of mortality after 45 min of treatment with $\mathrm{TiO}_{2}(\mathrm{ST} 01)$, $\mathrm{TiO}_{2}$ (ST41) and $\mathrm{TiO}_{2}$ (TIO6) samples, respectively. Under irradiation with visible light, an increase in antibacterial properties was noticed reaching $23.2 \%, 25.8 \%$ and $27.9 \%$, respectively. Under UV irradiation, significant increase in activity was observed, especially for the fine anatase sample (ST01, 93.1\%). Modification with gold caused a slight increase in activity under UV irradiation reaching $96.2 \%, 94.2 \%$ and $77.5 \%$, respectively. An increase in photocatalytic activity after titania modification with NPs of NMs is not surprising, due to a decrease in chargecarrier recombination since noble metals work as an electron sink [54]. The most interesting finding was a significant enhancement of activity under vis irradiation and in the dark. Under vis irradiation the antibacterial activity was increased four times for ST01 and TIO6 samples and three times for ST41 sample, and in the dark it was increased two, three and four times for TIO6, ST01 and ST41, respectively. It is proposed that inactivation of bacteria under visible light irradiation is mainly caused by plasmonic photocatalysis, i.e., the activation of titania by LSPR of gold with a probable electron transfer from gold NPs to the conduction band (CB) of titania and subsequent reduction of oxygen resulting in the formation of reactive oxygen species (ROS). It is also possible that bacteria could be easier adsorbed on positively charged (electron-defi- cient) gold NPs, and then directly oxidized with simultaneous electron transfer to gold NPs keeping them in the initial zero valent state. A similar mechanism was proposed for decomposition of organic compounds under vis irradiation [53]. The increase in dark activity of titania samples after modification with gold could be caused by an extracellular electron transfer between bacteria and gold, i.e., the surface of gold-modified titania could abstract respiration-active electrons from bacteria, inducing bacterial death [59]. In addition, silver and gold could affect proper transport through the plasma membrane by alteration of the membrane viscosity and disruption of ionic pumps [60]. It is assumed that fine gold NPs more effectively clogged the channels (called porins), which allowed for passive transports of various ions, amino acids and other important molecules. This mechanism is independent on light action [61-63]. In this mechanism, the photocatalyst properties such as particle shape, size and content of NPs could influence the efficiency on interaction between NPs and bacteria [64].

To evaluate the difference between dark activity and plasmonic photocatalysis, decomposition of bacterial cells in titania suspension with simultaneous measurements of evolved carbon dioxide was studied for bare and modified titania with gold or silver. Our preliminary studies on $\mathrm{TiO}_{2}(\mathrm{ST} 41)$ photocatalyst 
showed that although inactivation of bacterial cells was similar for bare and silver-modified samples (eight orders of decrease after three hours of vis irradiation and one order in the dark), only the silver-modified samples under vis irradiation caused continuous evolution of carbon dioxide suggesting a mineralization of bacterial cells [54]. To check if bacterial cells were really decomposed, scanning electron microscopy (SEM) observations were performed and the obtained data are shown in Figure 5 . It was found that $1 \mathrm{~h}$ of vis irradiation was sufficient to initiate the destruction of bacterial cell walls, and $3 \mathrm{~h}$ of irradiation resulted in the decomposition of bacterial cells with clear formation of protoplast.

For the other silver-modified samples $\left(\mathrm{Ag} / \mathrm{TiO}_{2}(\mathrm{FP} 6)\right.$ and $\mathrm{Ag} / \mathrm{TiO}_{2}(\mathrm{ST} 01)$ ) a similar tendency was observed, i.e., continuous evolution of carbon dioxide was observed for silver-modified samples under vis irradiation as shown in Figure 6. Carbon dioxide also evolved on silver-modified samples in the dark, but only during the first two hours. In contrast to $\mathrm{Ag} / \mathrm{TiO}_{2}(\mathrm{ST} 41)$, for which similar inactivation of bacteria was observed in the dark and under vis irradiation [35], a significantly larger activity for silver-modified samples was noticed under vis irradiation than that in the dark. The higher activity of $\mathrm{Ag} / \mathrm{TiO}_{2}$ (FP6) compared to $\mathrm{Ag} / \mathrm{TiO}_{2}(\mathrm{ST} 01)$ in the dark is presumably caused by larger NPs of silver in $\mathrm{Ag} / \mathrm{TiO}_{2}$ (FP6) (Table 1), because there is a tendency that antibacterial activity increases with an increase in the size of silver NPs [65]. Indeed, the highest activity in the dark was obtained for the large NPs of silver in the $\mathrm{Ag} / \mathrm{TiO}_{2}(\mathrm{ST} 41)$ sample. There are two possible explanations for the larger activity under vis irradiation: (1) bacteria inactivation by plasmonic photocatalysis (generation of ROS under vis irradiation) or (2) formation of larger amounts of positively charged silver and its subsequent release into bacteria-titania suspension (also through a plasmonic mechanism, as discussed above for gold). In order to clarify the exact mechanism under vis irradiation, the dependence of activity on the irradiation wavelength should be scrutinized, which is presently done. At the moment, it is clear that the activity of bare titania in the dark
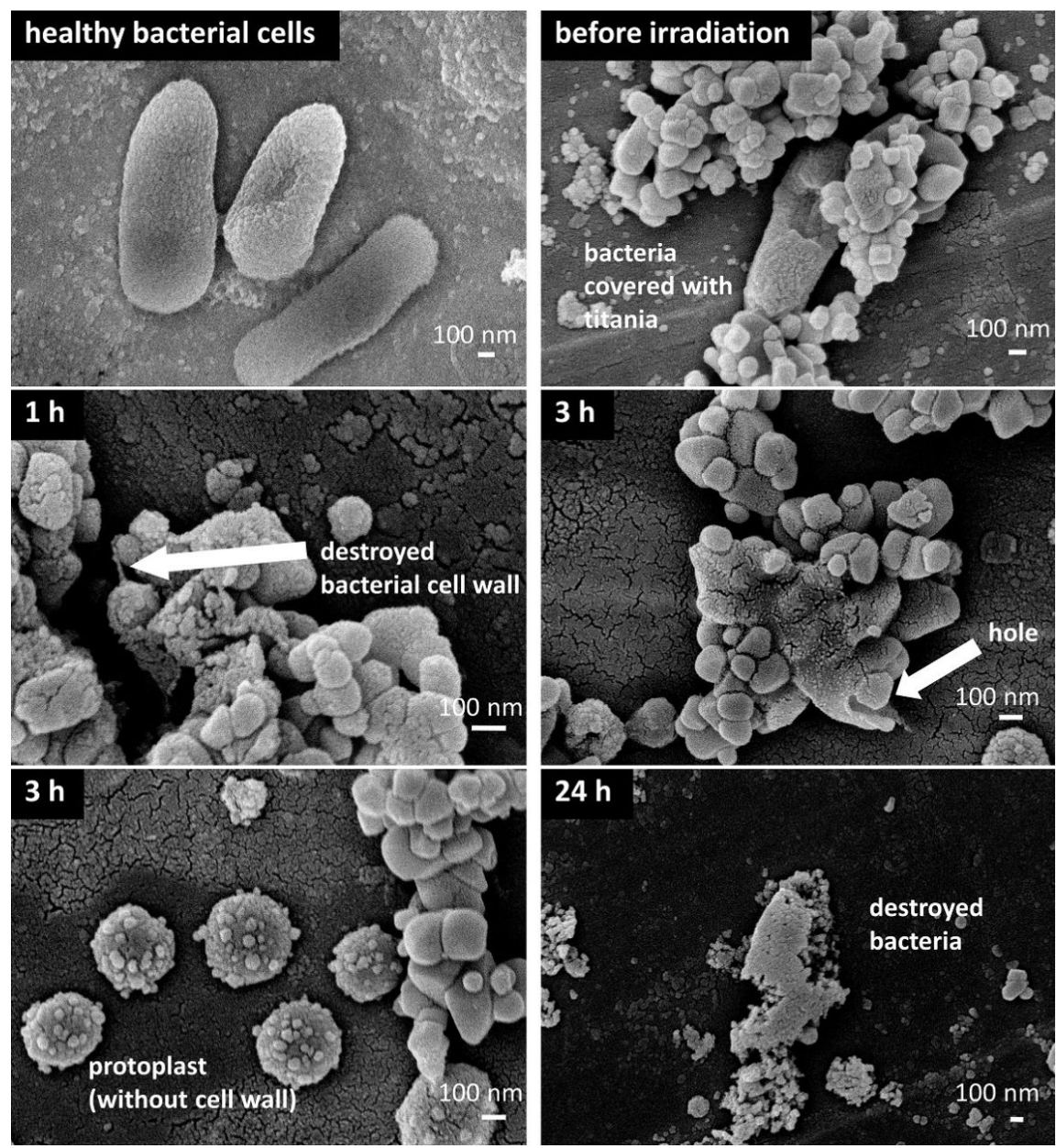

Figure 5: SEM images of the decomposition of bacterial cells under vis $(\lambda>420 \mathrm{~nm})$ irradiation on $\mathrm{Ag} / \mathrm{TiO}{ }_{2}(\mathrm{ST} 41)$ photocatalyst. 
and under vis irradiation is negligible compared to the high activity of the silver-modified samples. For comparison, a goldmodified sample $\left(\mathrm{Au} / \mathrm{TiO}_{2}\right.$ ( $\left.\mathrm{TIO} 12\right)$ ) was also tested, and the obtained data are shown in Supporting Information File 1 (Figure S1). For bare titania (TIO12, fine anatase), similar to other titania samples (ST01 and FP6 (Figure 6)), negligible activities under vis irradiation and in the dark, were noticed. A negligible activity of the gold-modified sample under dark conditions was observed, which was even lower than that of bare titania. It is proposed that very fine gold NPs on titania could disturb the binding of titania to the bacterial cells as a result of active site blocking by gold [66]. Thus a lower antibacterial activity was obtained. Under vis irradiation, a high antibacterial activity was observed, but significantly lower than that of the silver-modified samples (two to four orders of magnitude). Although, the activity of the gold-modified sample was lower, it is clear that it originated from plasmonic activation of titania. Probably, this is the first evidence proving antibacterial activity of plasmonic photocatalysts under visible-light irradiation $(\lambda>420 \mathrm{~nm})$, resulting only from plasmonic activation of titania. There was no activity in the dark and an inactivity of bare titania. Plasmonic activity of other photocatalysts has been reported, but silver-modified samples, also exhibit activity in the dark due to the antimicrobial effect of silver $[26,48,67,68]$. Although, gold-modified titania exhibited antibacterial activity under visible-light irradiation, the bacteria killing rate was much slower than that of the silver-modified samples (due to the high silver activity in the dark). Accordingly, it is proposed that silver-modified samples are more promising as antibacterial agents, due to high efficiency (both in the dark and under vis irradiation) as well as the lower price of silver.

\section{Antifungal activity of plasmonic photocatalysts}

High humidity, positive temperature and lack of proper ventilation are significant factors affecting the growth of mould fungi in indoor environment. Some moulds produce spores that pose a serious threat to human health, e.g., chronic fatigue and allergic asthma. Long-term exposure to indoor moulds aggravates mentioned symptoms and can promote new ones. Moreover, fungi as more complex microorganisms than bacteria and viruses are much more resistant to antimicrobial agents. Therefore, there is a great need to develop new efficient antifungal materials. Regarding this, the antifungal properties of plasmonic photocatalysts have been tested. At first, experiments were performed by disc diffusion, as exemplary shown in Supporting Information File 1 (Figures S2-S5). Small (0-5 mm) inhibition zones were observed only for Candida albicans for paper discs impregnated with $\mathrm{Ag} / \mathrm{TiO}_{2}(\mathrm{ST} 41)$ under vis irradiation. Consequently, it can be assumed that silver and gold ions are not releases from modified titania to the medium. All paper discs impregnated with silver-modified titania $\left(\mathrm{Ag} / \mathrm{TiO}_{2}(\mathrm{ST} 41)\right.$ and $\left.\mathrm{Ag} / \mathrm{TiO}_{2}(\mathrm{ST} 01)\right)$ and gold-modified titania $\left(\mathrm{Au} / \mathrm{TiO}_{2}(\mathrm{ST} 41)\right.$ and $\mathrm{Au} / \mathrm{TiO}_{2}(\mathrm{ST} 01)$ ) were avoided by all tested mould fungi under vis irradiation. This suggests that the antifungal effect is mainly associated with photocatalytic action. This effect was not observed for bare titania samples.

Mycelia of mould fungi, e.g., Aspergillus melleus, displayed a colour change in direct contact with paper discs impregnated with $\mathrm{Ag} / \mathrm{TiO}_{2}(\mathrm{ST} 01)$ and $\mathrm{Ag} / \mathrm{TiO}_{2}(\mathrm{ST} 41)$ in the dark and under vis irradiation due to inhibited sporulation. That effect was not observed for paper discs impregnated with bare and gold-modi-
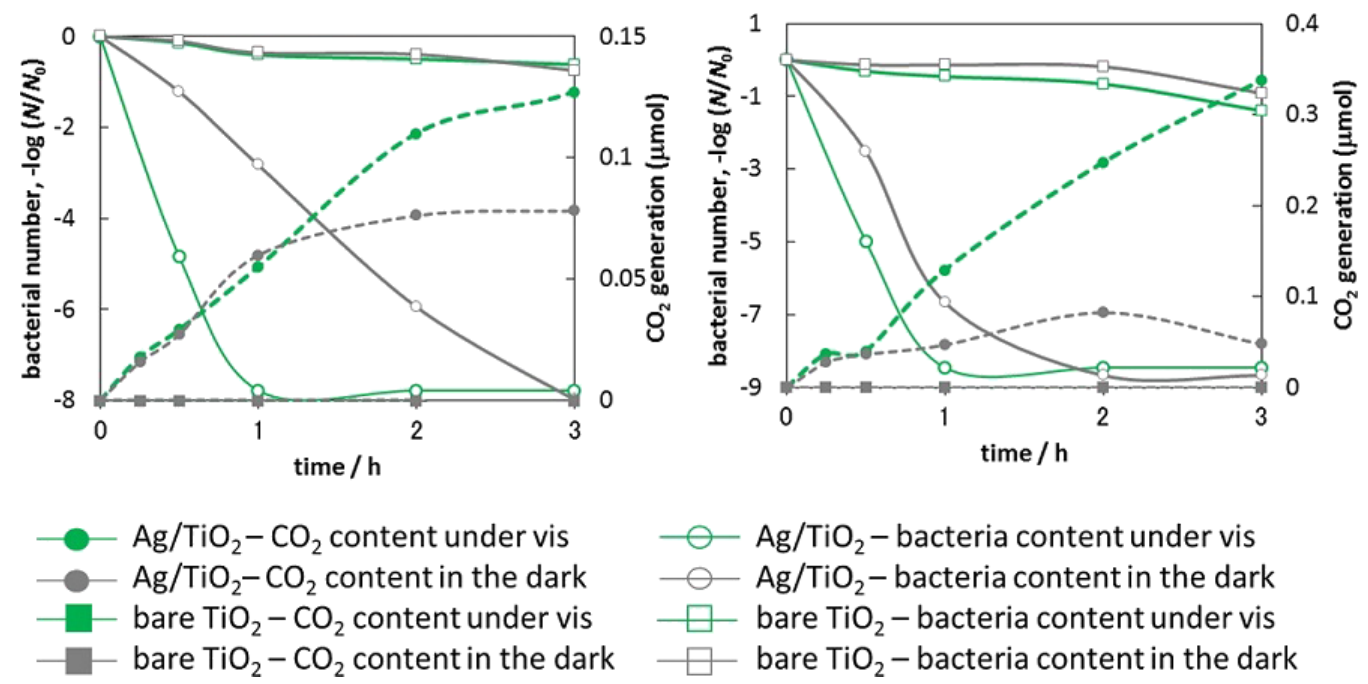

Figure 6: Number of $E$. coli bacteria (closed symbols) and evolution of $\mathrm{CO}_{2}$ (open symbols) during inactivation of bacterial cells in the dark (grey symbols) and under vis irradiation $\left(\lambda>420 \mathrm{~nm}\right.$; green symbols) on bare (squares) and modified titania (circles): (left) $\mathrm{TiO}_{2}(\mathrm{ST01})$ and $\mathrm{Ag} / \mathrm{TiO}{ }_{2}(\mathrm{ST} 01)$, (right) $\mathrm{TiO}_{2}(\mathrm{FP} 6)$ and $\mathrm{Ag} / \mathrm{TiO}_{2}(\mathrm{FP} 6)$. 
fied titania. The antifungal study based on disc diffusion showed ambiguous results for silver- and gold-modified titania samples. It may be concluded that a concentration of $1 \mathrm{~g} / \mathrm{L}$ of Ag- and Au-modified titania is not sufficient to observe a biocidal effect, regardless of the experimental conditions. As it was shown in our previous studies $[69,70]$, the photocatalytic degradation of fungi was much lower than that of bacteria, because of differences in inactivation mechanism and cell-wall structure. The potent activity of Ag-modified titania against yeast (C. albicans) was caused by its different morphology and taxonomy group. It is well known that yeast are unicellular fungi, and do not produce mycelia and spores, which makes them the most vulnerable object, i.e., a few times more sensitive towards antifungal agents than other fungi. Auyeung et al. found that only metallic and ZnO NPs showed a potent antimould activity against $A$. niger and P. chrysogenum [71].

Despite the low antifungal activity of silver-modified titania, the inhibition zones around paper disks may be considered as positive results indicating a high stability of photocatalysts. However, it should be concluded that the antifungal properties of silver-modified titania are not attractive for commercial application. Moreover, the small inhibition zones around discs were difficult to evaluate quantitatively. Therefore, the "poisoned food" method (fungal growth on titania/MEA support) with gold-modified titania was used for further investigations. At first, bare titania samples were examined, and obtained data are shown in Supporting Information File 1 (Figure S6). It was found that fungi, especially A. melleus, were sensitive to photocatalysis, and the highest activity was obtained for fine titania samples especially under vis irradiation. Interestingly, for $P$. chrysogenum and A. niger the same activity of bare titania FP6 was observed in the dark and under irradiation. It should be mentioned that both titania samples (ST01 and FP6) are highly active photocatalysts for various photocatalytic reactions, e.g., oxidative decomposition of acetic acid and dehydrogenation of methanol [72]. FP6 has larger crystals (smaller specific surface area), and thus its lower activity under irradiation is reasonable. Not only the diameter of the mycelium, but also the level of sporulation should be estimated for antifungal activity tests, and summarized data for mycelium growth and sporulation are shown in Supporting Information File 1 (Table S2, and exemplary photographs of fungal growth in Figure S7). It was confirmed that titania ST01 was more efficient than titania FP6. Next, gold-modified samples were examined, and antifungal properties of gold were confirmed in the dark, as shown in Figure 7 and in Supporting Information File 1 (Table S3).

Surprisingly, under fluorescent irradiation bare titania was more active than gold-modified titania. Noble metal-modified titania samples are usually more active under both UV and visible light irradiation than bare titania samples (see studies for sixteen commercial titania samples modified with gold [53] and silver $[43,54])$. However, in the near-UV range and in some cases, bare titania shows larger photocatalytic activity [45]. It should be reminded that the titania samples here are commercial samples, and thus with small content of impurities and defects, which can increase the visible-light activity of titania by narrowing of the band gap. The adsorbed gold on the titania surface would disturb this intrinsic vis response at 390-420 nm. Moreover, it should be clarified that the lower inhibition of mycelium growth does not unequivocally mean a lower antifungal action, since sporulation and possible mycotoxin generation must be also considered. Therefore, a decrease in sporulation and the inhibition of droplet formation (with possible presence of mycotoxins) on gold-modified titania indicate that goldmodified titania could be used as efficient antifungal agent.

Antifungal properties were also confirmed for other gold-modified titania samples (TIO12 and STF10), as shown in Supporting Information File 1 (Figures S8-S9). Although, the antifungal effect was clear, the evaluation of the overall antifungal activity was quite troublesome, due to the difficult differentiation between the colours of mycelium and support (modifiedtitania). Therefore, a new method, namely "spore counting" was applied (Supporting Information File 1, Figure S10), and the obtained data are shown in Figure 8. In the literature, contradictory opinions on the influence of light on fungi have been presented. Light can stimulate or inhibit fungal growth or be without any effect [73]. Most filamentous fungi are photophobic [74]. Light could limit (or even completely inhibit) germination, probably due to an increase in temperature during irradiation [75]. The inhibition effect increases with an increase in light energy, i.e., UVB $(280-320 \mathrm{~nm})$ is more harmful than UVA (320-400 nm). UV light in the solar spectrum is considered to be responsible for inhibition of mycotoxin generation [75]. It is known that fungi are heterotrophic organisms, and thus light is not necessary for their growth. However, it has been also reported that light may act on enzyme levels and metabolite secretion in fungal cells [75]. Our results clearly demonstrate that irradiation does not influence the sporulation of A. melleus and P. chrysogenum in the absence of titania. However, a significant effect on sporulation was observed for bare titania. Moreover, gold slightly enhanced this effect depending on the fungi species. P. chrysogenum was sensitive to light, which stimulated its growth, whereas irradiation almost did not influence the groth of $A$. melleus.

To the best of our knowledge, this is the first report on the effect of gold-modified titania on sporulation of mould fungi. It is clear that although a negligible inhibition of mycelium 

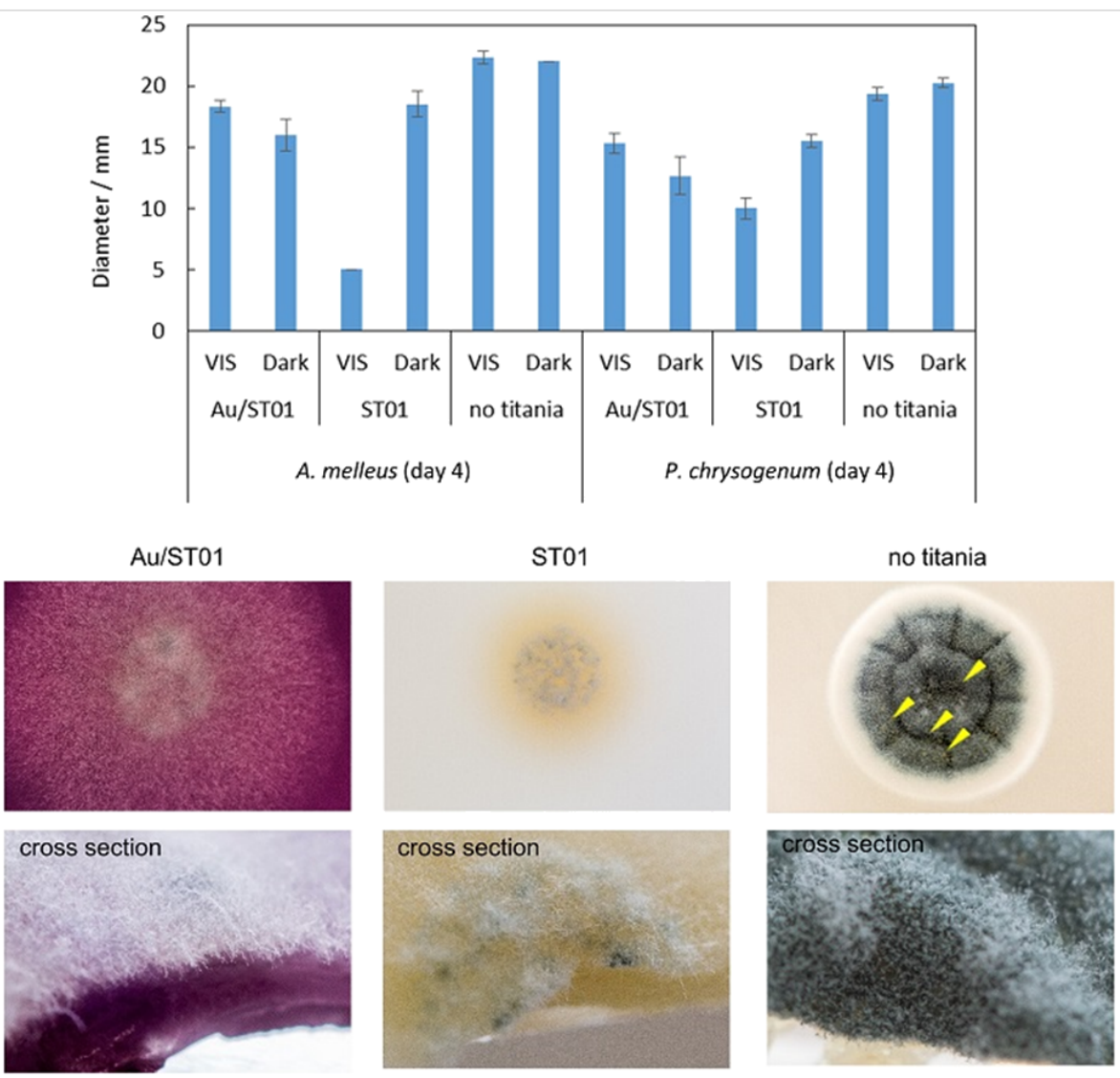

Figure 7: (top) Antifungal properties of bare and gold-modified titania ST01 by a comparison of diameters of colonies after four days of growth ( $n=6$ mean \pm S. D.), and (bottom) representative photograph of $P$. chrysogenum cultivated for four days under fluorescent-light irradiation. Arrowheads indicate the droplets.
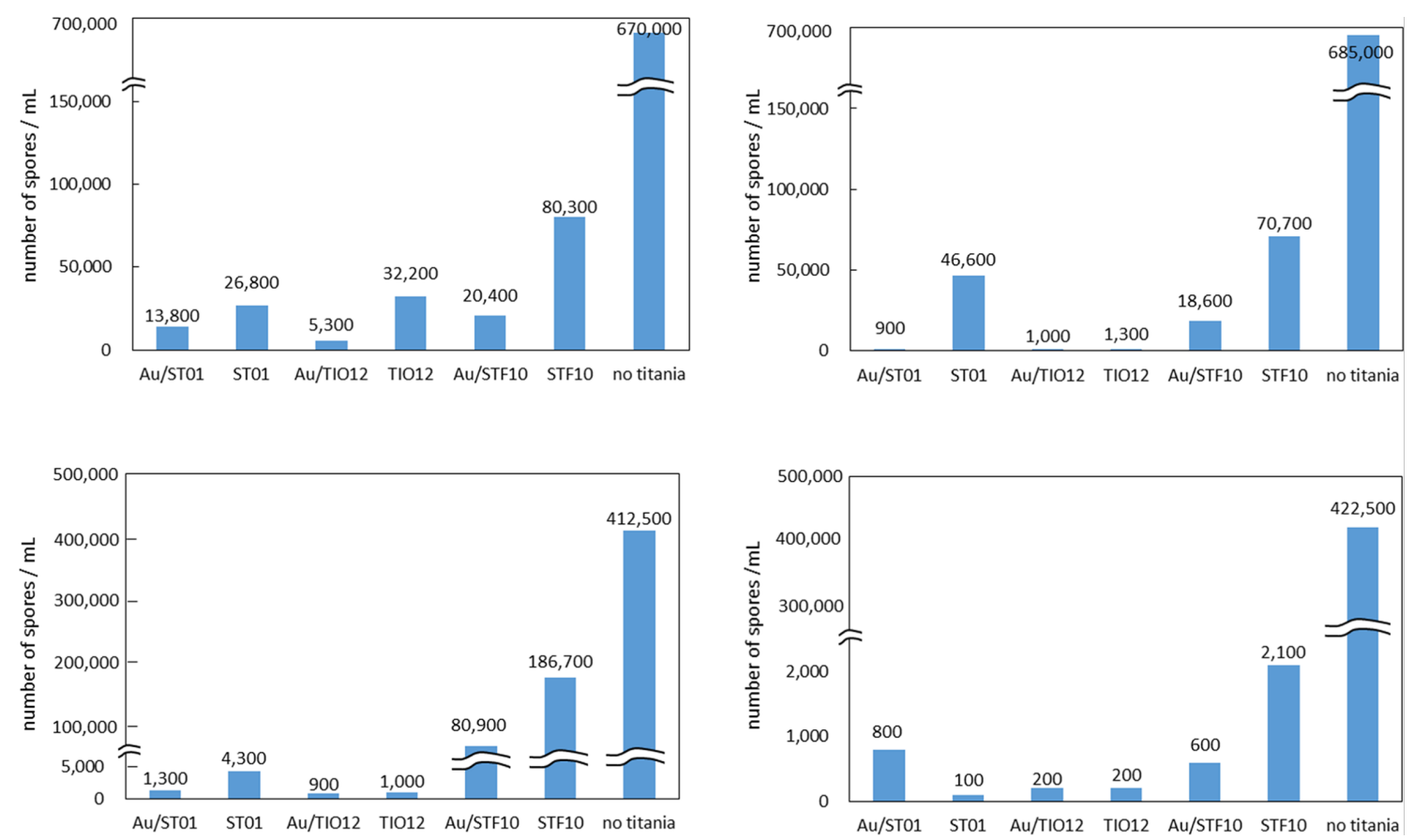

Figure 8: Sporulation after five days of growth of $P$. chrysogenum (top) and A. melleus (bottom) under vis light (left) and in the dark (right). 
growth was observed (Figure 7, and Figure S8 and Figure S9 and Table S3 in Supporting Information File 1), sporulation was inhibited almost completely (99.8\%) on slants supplemented with $\mathrm{Au} / \mathrm{TiO}_{2}$. In order to understand the function of $\mathrm{Au}$ NPs in the inhibition of sporulation, colloidal Au NPs (ca. $12 \mathrm{~nm}$ ) were investigated by the same method (Figure S11, Supporting Information File 1). It was found that unsupported Au NPs did not show inhibition of sporulation in the dark, and only a slight inhibition under visible-light irradiation for A. melleus. Accordingly, it is proposed that Au NPs do not intrinsically inhibit sporulation. It may be concluded that the $\mathrm{Au}-\mathrm{TiO}_{2}$ heterojunction is necessary to influence the formation of sporangia and/or spores during the growth of mycelium. Although, further investigation is necessary for the mechanism clarification, it is proposed that titania could change the availability of nutrients from media. Suberkropp has already reported that the nutrient availability and allocation of resources are main factors determining fungal reproduction (sporulation) [76]. It is proposed that the main reason of a decrease in media nourishment for mould fungi is probably caused by sorption of macromolecules (e.g., proteins and sugars) on titania, as suggested by Raffaini and Ganzoli [77] and Ellingsen [78].

On the other hand, our previous study showed that Au-modified faceted titania was inactive against $C$. albicans, in contrast to the Ag-modified sample [29]. It is assumed that different results could originate from different structures of the fungi. C. albicans is a dimorphic fungus since it grows as yeast, and it neither forms a mycelium nor produces reproductive cells (spores). It is proposed that Ag could penetrate the cell envelope easily and cause significant changes in survival rate, due to the simple cell structure of C. albicans. Accordingly, it is proposed that the bactericidal mechanism could be similar to the anti-“candida" mechanism, and different from antifungal mechanism for mould fungi.

Rogawansamy et al. have proposed that the best antifungal agent should inhibit the growth of various fungal genera, whereas less active antifungal agents could only inhibit sporulation or the growth of a limited range of fungi [79]. However, it should be reminded that spores are essential for fungal reproduction by expanding into the environment, and thus causing various allergies and respiratory diseases. Therefore, it is proposed that $\mathrm{Au} / \mathrm{TiO}_{2}$, which exhibits effective inhibition of sporulation, can be a promising material for reducing health-threatening factors in indoor environment.

\section{Conclusion}

Noble metal-modified titania photocatalysts exhibit good antimicrobial properties in the dark and under visible-light irradiation due to antimicrobial properties of noble metals and plas- monic photocatalysis. The surface properties of photocatalysts are crucial for the antimicrobial effect, and generally, a decrease in particle sizes results in an activity increase, due to a larger interface between microorganisms and photocatalysts. Silver-modified samples show high antibacterial activity (complete decomposition of bacterial cells), whereas gold-modified samples are very active against fungi, especially in the inhibition of sporulation. Therefore, it is expected that bimetallic $(\mathrm{Au} / \mathrm{Ag})$ titania photocatalysts should exhibit broad antimicrobial properties. The lack of inhibition zones around disks supplemented with photocatalysts confirms the high stability of photocatalysts and their commercial applicability.

\section{Experimental}

\section{Preparation of silver- and gold-modified $\mathrm{TiO}_{2}$}

$2 \mathrm{wt} \%$ of silver and gold were deposited on six commercial titania samples: ST01 (Ishihara, ST-01), ST41 (Ishihara, ST-41), TIO12 (TAYCA, JRC-TIO-12), FP6 (Showa Denko Ceramics, FP-6), TIO6 (Catalysis Society of Japan, JRC-TIO-6) and STF10 (Showa Denko Ceramics, ST-F10). In brief, $\mathrm{TiO}_{2}$ samples were suspended in a $50 \mathrm{vol} \%$ aqueous solution of methanol, to which either $\mathrm{AgNO}_{3}$ aqueous solution or $\mathrm{HAuCl}_{4} \cdot \mathrm{H}_{2} \mathrm{O}$ aqueous solution was added, suspensions were purged with argon for $15 \mathrm{~min}$, and irradiated with a $400 \mathrm{~W}$ mercury lamp in a thermostatic water bath at $298 \mathrm{~K}$ under stirring $(500 \mathrm{rpm})$. The obtained noble metal-modified $\mathrm{TiO}_{2}$ samples were centrifuged, washed twice with methanol and twice with Milli-Q water and dried at $378 \mathrm{~K}$.

\section{Antibacterial activity test}

$50 \mathrm{mg}$ of the sample was dispersed in $7.0 \mathrm{~mL}$ of E. coli $\mathrm{K} 12$ (ATCC29425) suspension at a concentration of ca. 0.180 Abs at $630 \mathrm{~nm}$ (ca. $1-5 \times 10^{8}$ cells $/ \mathrm{mL}$ ) in a test tube with stirring bar and irradiated with a xenon lamp (with CM1 and Y-45 filter; $\lambda>420 \mathrm{~nm})$ or kept in the dark. Serial dilutions $\left(10^{-1}\right.$ to $\left.10^{-6}\right)$ were prepared and aliquots of suspensions were inoculated on Plate Count Agar (Becton, Dickinson and Company, USA) media after $0,0.5,1,2$ and $3 \mathrm{~h}$. Media were incubated at $37^{\circ} \mathrm{C}$ overnight and then colonies were counted. Simultaneously, generated $\mathrm{CO}_{2}$ was measured by FID-gas chromatography.

For SEM observation, $0.1 \mathrm{~mL}$ of the mixture of E. coli $\mathrm{K} 12$ and sample before and after reaction was collected, diluted 10 times with sterile Milli-Q water and mounted on a piece of copper tape. The bacterial cells were fixed by $2.0 \%$ glutaraldehyde and $2.0 \%$ paraformaldehyde in $30 \mathrm{mM}$ HEPES buffer for $1 \mathrm{~h}$. After fixation, cells were washed with $30 \mathrm{mM}$ HEPES buffer for $1 \mathrm{~min}$, dehydrated by a graded series of ethanol (30, 50, 70, 90, 95 and $99.5 \%(\mathrm{v} / \mathrm{v}))$ for $10 \mathrm{~min}$ each. Then, samples were washed with tert-butyl alcohol three times, soaked in it and dried under vacuum. Samples were sputtered with platinum for 
$60 \mathrm{~s}$ from three directions and observed by SEM (JSM-7400F, JEOL).

\section{Antifungal activity test}

The antifungal tests were performed with the following microorganisms: the yeast Candida albicans, isolated from patients (throat smear) with immunodeficiency disorders that cause candidiasis (IIT\&EE ZUT collection), and mould fungi Aspergillus niger, Aspergillus melleus and Penicillium chrysogenum, isolated from damp basement air (IIT\&EE ZUT collection). The antimicrobial activity of the photocatalysts was tested by using disc diffusion [80]. Culture plates were prepared with $20 \mathrm{~mL}$ of two solid media: Sabouraud Glucose Agar SGA (BIOCORP, Poland) for C. albicans and Malt Extract Agar (Merck, Germany) for mould fungi. Sterilized culture media were poured in Petri dishes and, after solidification of the medium, $0.25 \mathrm{~mL}$ of fungal suspension was spread on the plate using an L-rod. The concentration of microorganisms was ca. $10^{6} \mathrm{CFU} / \mathrm{mL}$. The sterile paper discs (Whatman No.1, diameter $5 \mathrm{~mm})$ impregnated with photocatalyst suspension $(1 \mathrm{~g} / \mathrm{L}$ $10 \mu \mathrm{L} /$ disc) were placed at different locations on the culture plates. The control discs were impregnated with saline solution $(0.9 \% \mathrm{NaCl})$. One part of the plates was incubated in the dark, while another part was exposed to the indoor light. The natural indoor light from windows (intensity of ca. 120 lx) was strengthened by $8 \mathrm{~h}$ of exposure to a halogen lamp (intensity of ca. 400-500 1x). The distance from three halogen lamps to the plates was ca. $50 \mathrm{~cm}$. The temperature was maintained at ca. $30^{\circ} \mathrm{C}$ for C. albicans and $25^{\circ} \mathrm{C}$ for A. niger, A. melleus and $P$. chrysogenum. The incubation periods were $48 \mathrm{~h}$ for C. albicans and $72 \mathrm{~h}$ for mould fungi. After incubation, the zones of inhibition around the paper discs were investigated.

\section{Colony growth test}

$20 \mathrm{~g} / \mathrm{L}$ of the sample was dispersed in Malt Extract Agar (MEA) medium, sonicated for $1 \mathrm{~min}$, autoclaved at $121^{\circ} \mathrm{C}$ for $10 \mathrm{~min}$ and poured in Petri dishes. The spores of A. niger, A. melleus and P. chrysogenum were collected with $8.5 \mathrm{~g} / \mathrm{L}$ $\mathrm{NaCl}$ aqueous solution, and the suspension was inoculated on the Petri dishes. Dishes were irradiated with fluorescence light or kept in dark. After three and eight days of exposure the diameters of colonies were measured and the appearances were checked visually.

\section{Sporulation test}

$20 \mathrm{~g} / \mathrm{L}$ of the sample was dispersed in MEA medium, sonicated for $1 \mathrm{~min}$, autoclaved at $121^{\circ} \mathrm{C}$ for $10 \mathrm{~min}$ and dispensed to the slants. The spores of $A$. melleus and $P$. chrysogenum were collected with $8.5 \mathrm{~g} / \mathrm{L} \mathrm{NaCl}$ aqueous solution, the number of spores were counted by Thoma hemacytometers and $10,000 \mathrm{spores} / \mathrm{mL}$ of the suspension was inoculated on the slants. The slants were irradiated with fluorescence light or kept in dark. Triton X-100 (0.05\%) in $8.5 \mathrm{~g} / \mathrm{L} \mathrm{NaCl}$ aqueous solution was added to the culture after five days and mixed with a vortex mixer. Collected spores were diluted 10-50 times with $8.5 \mathrm{~g} / \mathrm{L} \mathrm{NaCl}$ aqueous solution, and then counted.

\section{Supporting Information}

\section{Supporting Information File 1}

Additional experimental data.

[https://www.beilstein-journals.org/bjnano/content/

supplementary/2190-4286-9-77-S1.pdf]

\section{Acknowledgements}

This research was supported by a Grand Challenges Explorations Grant (GCE R8, OPP1060234) from Bill and Melinda Gates Foundation. We also thank Yuji Kimura for preparation of $\mathrm{Au} / \mathrm{TiO}_{2}$ (TIO6) sample.

\section{ORCID ${ }^{\circledR}$ iDs}

Zhishun Wei - https://orcid.org/0000-0001-7436-6409

Ewa Kowalska - https://orcid.org/0000-0003-0955-9268

\section{References}

1. Blackman, A. Rev. Environ. Econ. Policy 2010, 4, 234-253. doi:10.1093/reep/req005

2. Blancou, J. Rev. Sci. Tech. (OIE) 1995, 14, 31-39.

3. Yang, H.; Cheng, H. Sep. Purif. Technol. 2007, 56, 392-396. doi:10.1016/j.seppur.2007.05.036

4. Zhang, L.; Gu, F. X.; Chan, J. M.; Wang, A. Z.; Langer, R. S.; Farokhzad, O. C. Clin. Pharmacol. Ther. (Hoboken, NJ, U. S.) 2008, 83, 761-769. doi:10.1038/sj.clpt.6100400

5. Pradeep, T.; Anshup. Thin Solid Films 2009, 517, 6441-6478. doi:10.1016/j.tsf.2009.03.195

6. Qu, X.; Alvarez, P. J. J.; Li, Q. L. Water Res. 2013, 47, 3931-3946. doi:10.1016/j.watres.2012.09.058

7. Arslan, I.; Balcioglu, I. A.; Tuhkanen, T. Environ. Technol. 1999, 20, 921-931. doi:10.1080/09593332008616887

8. Kowalska, E.; Janczarek, M.; Hupka, J.; Grynkiewicz, M. Water Sci. Technol. 2004, 49, 261-266.

9. Barbeni, M.; Minero, C.; Pelizzetti, E.; Borgarello, E.; Serpone, N. Chemosphere 1987, 16, 2225-2237. doi:10.1016/0045-6535(87)90281-5

10. Artuna, E.; Hupka, J. Cent. Eur. J. Public Health 2000, 8, 88-89.

11. Mozia, S.; Tomaszewska, M.; Morawski, A. W. Desalination 2006, 190 , 308-314. doi:10.1016/j.desal.2006.03.001

12. King, C. H.; Shotts, E. B., Jr.; Wooley, R. E.; Porter, K. G. Appl. Environ. Microbiol. 1988, 54, 3023-3033.

13. Mokrini, A.; Ousse, D.; Esplugas, E. Water Sci. Technol. 1997, 35, 95-102.

14. Tomova, D.; Iliev, V.; Rakovsky, S.; Anachkov, M.; Eliyas, A.; Li Puma, G. J. Photochem. Photobiol., A 2012, 231, 1-8. doi:10.1016/j.jphotochem.2011.12.012 
15. Hoffmann, M. R.; Martin, S. T.; Choi, W.; Bahnemann, D. W. Chem. Rev. 1995, 95, 69-96. doi:10.1021/cr00033a004

16. Cunningham, J.; Fox, M. A.; Pelizzetti, E.; Pichat, P.; Serpone, N. Photocatalytic treatment of waters. Aquatic and surface photochemistry; Lewis Publishers: Boca Raton, FL, U.S.A., 1994; pp 261-316.

17. Duffy, J. E.; Anderson, M. A.; Hill, C. G.; Zeltner, W. A. Ind. Eng. Chem. Res. 2000, 39, 3698-3706. doi:10.1021/ie990941o

18. Sánchez-Oneto, J.; Mancini, F.; Portela, J. R.; Nebot, E.; Cansell, F.; Martínez de la Ossa, E. J. Chem. Eng. J. 2008, 144, 361-367. doi:10.1016/j.cej.2008.01.041

19. Legrini, O.; Oliveros, E.; Braun, A. M. Chem. Rev. 1993, 93, 671-698. doi:10.1021/cr00018a003

20. Malato, S.; Blanco, J.; Richter, C.; Curco, D.; Gimenez, J. Water Sci. Technol. 1997, 35, 157-164.

21. Paz, Y. Appl. Catal., B 2010, 99, 448-460. doi:10.1016/j.apcatb.2010.05.011

22. Murakami, N.; Kurihara, Y.; Tsubota, T.; Ohno, T. J. Phys. Chem. C 2009, 113, 3062-3069. doi:10.1021/jp809104t

23. Yang, H. G.; Sun, C. H.; Qiao, S. Z.; Zou, J.; Liu, G.; Smith, S. C.; Cheng, H. M.; Lu, G. Q. Nature 2008, 453, 638-U4. doi:10.1038/nature06964

24. Wu, J.-J.; Yu, C.-C. J. Phys. Chem. B 2004, 108, 3377-3379. doi:10.1021/jp0361935

25. Janczarek, M.; Kowalska, E.; Ohtani, B. Chem. Eng. J. 2016, 289 , 502-512. doi:10.1016/j.cej.2016.01.008

26. Wei, Z.; Kowalska, E.; Verrett, J.; Colbeau-Justin, C.; Remita, H.; Ohtani, B. Nanoscale 2015, 7, 12392-12404. doi:10.1039/C5NR02386F

27. Kouamé, N. A.; Alaoui, O. T.; Herissan, A.; Larios, E.; José-Yacaman, M.; Etcheberry, A.; Colbeau-Justin, C.; Remita, H. New J. Chem. 2015, 39, 2316-2322. doi:10.1039/C4NJ01979B

28. Jaffrezic-Renault, N.; Pichat, P.; Foissy, A.; Mercier, R. J. Phys. Chem. 1986, 90, 2733-2738. doi:10.1021/j100403a035

29. Ząbek, P.; Eberl, J.; Kisch, H. Photochem. Photobiol. Sci. 2009, 8, 264-269. doi:10.1039/b812798k

30. Janus, M.; Tryba, B.; Inagaki, M.; Morawski, A. W. Appl. Catal., B: Environ. 2004, 52, 61-67. doi:10.1016/j.apcatb.2004.03.011

31. Yang, D.; Sun, Y.; Tong, Z.; Tian, Y.; Li, Y.; Jiang, Z. J. Phys. Chem. C 2015, 119, 5827-5835. doi:10.1021/jp511948p

32. Chen, Q.; Wu, S.; Xin, Y. Chem. Eng. J. 2016, 302, 377-387. doi:10.1016/j.cej.2016.05.076

33. Asahi, R.; Morikawa, T.; Ohwaki, T.; Aoki, K.; Taga, Y. Science 2001, 293, 269-271. doi:10.1126/science.1061051

34. Zaleska, A. Recent Pat. Eng. 2008, 2, 157-164. doi:10.2174/187221208786306289

35. Ohno, T.; Akiyoshi, M.; Umebayashi, T.; Asai, K.; Mitsui, T.; Matsumura, M. Appl. Catal., A 2004, 265, 115-121. doi:10.1016/j.apcata.2004.01.007

36. Dozzi, M. V.; Selli, E. J. Photochem. Photobiol., C 2013, 14, 13-28. doi:10.1016/j.jphotochemrev.2012.09.002

37. Li, G.; Dimitrijevic, N. M.; Chen, L.; Rajh, T.; Gray, K. A. J. Phys. Chem. C 2008, 112, 19040-19044. doi:10.1021/jp8068392

38. Marschall, R. Adv. Funct. Mater. 2014, 24, 2421-2440. doi:10.1002/adfm.201303214

39. Barreca, D.; Fornasiero, P.; Gasparotto, A.; Gombac, V.; Maccato, C.; Montini, T.; Tondello, E. ChemSusChem 2009, 2, 230-233. doi:10.1002/cssc.200900032
40. Wang, G.; Chen, Q.; Xin, Y.; Liu, Y.; Zang, Z.; Hu, C.; Zhang, B. Electrochim. Acta 2016, 222, 1903-1913. doi:10.1016/j.electacta.2016.11.182

41. Kraeutler, B.; Bard, A. J. J. Am. Chem. Soc. 1978, 100, 4317-4318. doi:10.1021/ja00481a059

42. Kowalska, E.; Remita, H.; Colbeau-Justin, C.; Hupka, J.; Belloni, J. J. Phys. Chem. C 2008, 112, 1124-1131. doi:10.1021/jp077466p

43. Kowalska, E.; Yoshiiri, K.; Wei, Z.; Zheng, S.; Kastl, E.; Remita, H.; Rau, S.; Ohtani, B. Appl. Catal., B: Environ. 2015, 178, 133-143. doi:10.1016/j.apcatb.2014.10.003

44. Tian, Y.; Tatsuma, T. J. Am. Chem. Soc. 2005, 127, 7632-7637. doi:10.1021/ja042192u

45. Verbruggen, S. W.; Keulemans, M.; Goris, B.; Blommaerts, N.; Bals, S.; Martens, J. A.; Lenaerts, S. Appl. Catal., B 2016, 188, 147-153. doi:10.1016/j.apcatb.2016.02.002

46. Lemire, J. A.; Harrison, J. J.; Turner, R. J. Nat. Rev. Microbiol. 2013, 11, 371-384. doi:10.1038/nrmicro3028

47. Rodríguez-Chueca, J.; Ormad, M. P.; Mosteo, R.; Sarasa, J.; Ovelleiro, J. L. Water Environ. Res. 2015, 87, 281-288. doi:10.2175/106143014X13987223590362

48. Wei, Z.; Endo, M.; Wang, K.; Charbit, E.; Markowska-Szczupak, A.; Ohtani, B.; Kowalska, E. Chem. Eng. J. 2017, 318, 121-134. doi:10.1016/j.cej.2016.05.138

49. Benabbou, A. K.; Derriche, Z.; Felix, C.; Lejeune, P.; Guillard, C. Appl. Catal., B 2007, 76, 257-263. doi:10.1016/j.apcatb.2007.05.026

50. Guillard, C.; Bui, T.-H.; Felix, C.; Moules, V.; Lina, B.; Lejeune, P. C. R. Chim. 2008, 11, 107-113. doi:10.1016/j.crci.2007.06.007

51. Zielińska, A.; Kowalska, E.; Sobczak, J. W.; Łącka, I.; Gazda, M.; Ohtani, B.; Hupka, J.; Zaleska, A. Sep. Purif. Technol. 2010, 72, 309-318. doi:10.1016/j.seppur.2010.03.002

52. Zielińska-Jurek, A.; Wei, Z.; Wysocka, I.; Szweda, P.; Kowalska, E. Appl. Surf. Sci. 2015, 353, 317-325. doi:10.1016/j.apsusc.2015.06.065

53. Kowalska, E.; Mahaney, O. O. P.; Abe, R.; Ohtani, B. Phys. Chem. Chem. Phys. 2010, 12, 2344-2355. doi:10.1039/b917399d

54. Kowalska, E.; Wei, Z.; Karabiyik, B.; Herissan, A.; Janczarek, M.; Endo, M.; Markowska-Szczupak, A.; Remita, H.; Ohtani, B. Catal. Today 2015, 252, 136-142. doi:10.1016/j.cattod.2014.10.038

55. Min, B. K.; Wallace, W. T.; Goodman, D. W. Surf. Sci. 2006, 600, L7. doi:10.1016/j.susc.2005.10.024

56. Ohtani, B.; Mahaney, O. O. P.; Amano, F.; Murakami, N.; Abe, R. J. Adv. Oxid. Technol. 2010, 13, 247-261. doi:10.1515/jaots-2010-0303

57. Zheng, S.; Wang, K.; Wei, Z.; Yoshiiri, K.; Braumuller, M.; Rau, S.; Ohtani, B.; Kowalska, E. J. Adv. Oxid. Technol. 2016, 19, 208-217.

58. Xia, Y.; Xiong, Y.; Lim, B.; Skrabalak, S. E. Angew. Chem., Int. Ed. 2008, 48, 60-103. doi:10.1002/anie.200802248

59. Wang, G.; Feng, H.; Gao, A.; Hao, Q.; Jin, W.; Peng, X.; Li, W.; Wu, G.; Chu, P. K. ACS Appl. Mater. Interfaces 2016, 8, 24509-24516. doi:10.1021/acsami.6b10052

60. Zeyons, O.; Thill, A.; Chauvat, F.; Menguy, N.; Cassier-Chauvat, C.; Oréar, C.; Daraspe, J.; Auffan, M.; Rose, J.; Spalla, O. Nanotoxicology 2009, 3, 284-295. doi:10.3109/17435390903305260

61. Soloviev, A.; Zholos, A.; Ivanova, I.; Novokhatska, T.; Tishkin, S.; Raevska, A.; StroyukC, A.; Yefanov, V. Vasc. Pharmacol. 2015, 72 , 190-196. doi:10.1016/j.vph.2015.05.016

62. Chin, C.; Park, Y. S. Cardiol. Ther. 2016, 5, 101-108. doi:10.1007/s40119-016-0060-8

63. Halawani, E. M. Int. J. Curr. Microbiol. Appl. Sci. 2016, 5, 397-414. doi:10.20546/ijcmas.2016.502.045 
64. Wang, L. L.; Hu, C.; Shao, L. Q. Int. J. Nanomed. 2017, 12, 1227-1249. doi:10.2147/IJN.S121956

65. Cao, H.; Qiao, Y.; Liu, X.; Lu, T.; Cui, T.; Meng, F.; Chu, P. K. Acta Biomater. 2013, 9, 5100-5110. doi:10.1016/j.actbio.2012.10.017

66. Mogyorósi, K.; Kmetykó, A.; Czirbus, N.; Veréb, G.; Sipos, P.; Dombi, A. React. Kinet. Catal. Lett. 2009, 98, 215-225. doi:10.1007/s11144-009-0052-y

67. Rtimi, S.; Baghriche, O.; Sanjines, R.; Pulgarin, C.; Bensimon, M.; Kiwi, J. J. Photochem. Photobiol., A 2013, 256, 52-63. doi:10.1016/j.jphotochem.2013.02.005

68. Rtimi, S.; Pascu, M.; Sanjines, R.; Pulgarin, C.; Ben-Simon, M.; Houas, A.; Lavanchy, J.-C.; Kiwi, J. Appl. Catal., B 2013, 138-139, 113-121. doi:10.1016/j.apcatb.2013.01.066

69. Markowska-Szczupak, A.; Ulfig, K.; Morawski, A. W. J. Adv. Oxid. Technol. 2012, 15, 30-33. doi:10.1515/jaots-2012-0103

70. Markowska-Szczupak, A.; Janda, K.; Wang, K.; Morawski, A. W.; Kowalska, E. Cent. Eur. J. Public Health 2015, 23, 267-271. doi:10.21101/cejph.a4054

71. Auyeung, A.; Casillas-Santana, M. A.; Martínez-Castañón, G. A.; Slavin, Y. N.; Zhao, W.; Asnis, J.; Häfeli, U. O.; Bach, H. PLoS One 2017, 12, e0169940. doi:10.1371/journal.pone.0169940

72. Prieto-Mahaney, O.-O.; Murakami, N.; Abe, R.; Ohtani, B. Chem. Lett. 2009, 38, 238-239. doi:10.1246/cl.2009.238

73. Nielsen, K. F. Fungal Genet. Biol. 2003, 39, 103-117. doi:10.1016/S1087-1845(03)00026-4

74. Fargues, J.; Rougier, M.; Goujet, R.; Smits, N.; Coustere, C.; Itier, B. J. Invertebr. Pathol. 1997, 69, 70-78. doi:10.1006/jipa.1996.4637

75. Willocquet, L.; Colombet, D.; Rougier, M.; Fargues, J.; Clerjeau, M. Eur. J. Plant Pathol. 1996, 102, 441-449. doi:10.1007/BF01877138

76. Suberkropp, K. Can. J. Bot. 1995, 73, S1361-S1369. doi:10.1139/b95-398

77. Raffaini, G.; Ganazzoli, F. Philos. Trans. R. Soc. London, Ser. A 2012, 370, 1444-1462. doi:10.1098/rsta.2011.0266

78. Ellingsen, J. E. Biomaterials 1991, 12, 593-596. doi:10.1016/0142-9612(91)90057-H

79. Rogawansamy, S.; Gaskin, S.; Taylor, M.; Pisaniello, D. Int. J. Environ. Res. Public Health 2015, 12, 6319-6332. doi:10.3390/ijerph120606319

80. Markov, S. L.; Vidaković, A. M. Acta Period. Technol. 2014, 141-152. doi:10.2298/APT1445141M

\section{License and Terms}

This is an Open Access article under the terms of the Creative Commons Attribution License (http://creativecommons.org/licenses/by/4.0), which permits unrestricted use, distribution, and reproduction in any medium, provided the original work is properly cited.

The license is subject to the Beilstein Journal of Nanotechnology terms and conditions: (https://www.beilstein-journals.org/bjnano)

The definitive version of this article is the electronic one which can be found at:

doi:10.3762/bjnano.9.77 